\title{
JAK URODZIĆ SAMĄ SIEBIE?
}

\author{
EWA WOJCIECHOWSKA
}

\begin{abstract}
Abstrakt: Recenzja książki: Katarzyna Czeczot. 2016. Ofelizm. Romantyczne zawłaszczenia, feministyczne interwencje. Warszawa: Wydawnictwo IBL PAN.
\end{abstract}

Słowa kluczowe: emancypacja, feminizm, literatura, romantyzm

Bohaterką książki Katarzyny Czeczot jest Ofelia - trup pięknej dziewczyny, otoczony kwiatami, płynący z prądem rzeki. Łączy się w niej kobiecość, seksualność, natura, szaleństwo i śmierć ten obraz ma w historii Zachodu długa, wykraczająca znacznie poza Szekspirowski dramat tradycję. Dzieli ona rzeczywistość na dwie strony: męską i żeńska, gdzie męskości przypisuje się aktywność, sprawczość, podmiotowość, kulturę i racjonalność, zaś kobiecości - pasywność, podległość, naturę, emocjonalność i cielesność. Kobieta jest tym samym silniej niż mężczyzna związana z przyroda i zdeterminowana przez własne ciało. Wyraźnie pokazuje tę asymetrię relacja między Hamletem i Ofelią: podczas gdy zachowanie duńskiego księcia interpretuje się w kategoriach egzystencjalnych i filozoficznych, w wypadku Ofelii podkreśla się brak sprawczości dziewczyny. Jej utonięcie - być może gwałtowny sprzeciw lub akt wyboru przedstawia się jako nieintencjonalne potknięcie, jakby to sama przyroda (drzewo, woda) przywoływała ją syrenim śpiewem. 
Wszyscy chcą dysponować ciałem Ofelii. Ojciec najpierw instruuje ja, by nie dopuszczała do siebie Hamleta, by następnie zmusić do odegrania upokarzającej sceny, podglądanej przez niego samego i Króla, co wzmocnić ma pozycję Poloniusza na dworze. Hamlet z kolei igra z dziewczyna, na przykład przez nieoczekiwane, wulgarne erotyczne aluzje, których się potem wypiera. Królowa z kolei sugeruje, że jej śmierć miała coś wspólnego z utratą wianka. Tak więc to inni decydują za Ofelię - inni ludzie, bądź natura, cielesność, nad którą bohaterka nie ma żadnej kontroli - i jako taka, zewnątrzsterowna i skazana na szaleństwo, a potem śmierć, zostaje unieruchomiona, niejako zabezpieczona w pięknym obrazie, wskutek czego nie może się zbuntować i zagrozić stabilności porządku, który ją wykorzystuje i krzywdzi.

Czeczot chce ten obraz poruszyć - lub inaczej, zobaczyć jako niejednoznaczny, wewnętrznie sprzeczny (dlatego ofelizm może być zarówno konserwatywny, jak i emancypacyjny, może dotyczyć kobiet i mężczyzn, etc.), ciagle pracujący i ciagle w ruchu. Nie chodzi tu o reinterpretację postaci Ofelii, historii reprezentacji kobiecego szaleństwa czy samobójstwa ani katalogowanie motywów ofelicznych; autorka odmawia sprowadzenia swojej bohaterki w jej różnych wcieleniach do jednoznacznego celu: do potencjalnej feministycznej sojuszniczki czy kandydatki na rewolucyjny sztandar. Chodzi zaś o ten jeden obraz (Benjaminowski obraz dialektyczny, kod wizualny, jak nazwałaby go Czeczot) - młodą kobietę, która ginie samobójcza śmiercią w otoczeniu wody i kwiatów, a jej śmierć łączy się z szaleństwem, naturą i seksualnością. Badanie go służy rozmaitym celom, takim jak rewizje romantyzmu, krytyka protekcjonalnych mechanizmów wiktymizacji oraz pytanie o warunki możliwości emancypacji kobiety jako silnej poetki, analogicznej do silnego poety Harolda Blooma, który przekraczając swojego poprzednika rodzi sam siebie. Przywołuję kontekst Lęku przed wptywem nie bez powodu - sugeruje go sama autorka w rozdziale o Adèle Hugo, jednak kwestia silnej poetki i walki o to, by urodzić samą siebie wydaje mi się czymś więcej niż jednorazowo wykorzystanym narzędziem interpretacyjnym. Bloomowska energia agoniczna przenika całą tę książkę. Jednym z jej przykładów jest żywiołowy opór wobec wiktymizacji.

Skoro mowa o nieszczęśliwych dziewczynach, które topią się z powodu fatalnej miłości, to romantyzm pokazuje nam cała galerię takich bohaterek. A kiedy mówimy „dziewczyny”, musimy dopowiedzieć od razu, że mowa o chłopkach, romantyczne uwiedzenie jest bowiem sprawą klasowa. Rola uwodzącego przypada panu, szlachcicowi, który stoi na pozycji władzy, zaś uwiedzioną jest wieśniaczka, wykorzystana, bezbronna bohaterka o czystym sercu. Dziewiętnastowieczni pisarze chętnie podejmowali ten temat, zazwyczaj przedstawiając chłopki jako prostoduszne ofiary pańskiego kaprysu. Zdawać by się mogło, że takie rejestry krzywd zadawanych niewinnym dziewczętom przez zepsutych szlachciców, potępiające degenerację panów, niosły wywrotowy, demokratyczny przekaz. W istocie często działały odwrotnie, pozorami współczucia maskując obronę status quo. 
Czeczot obnaża ten mechanizm odważnie reinterpretując Ulane Kraszewskiego, powieść odbierana jako dowód wrażliwości autora na losy kobiet i ludu. Utworem ekscytował się sam Czerwony Kasztelanic, Edward Dembowski, który wychwala linię ideową Ulany jako godny pochwały przykład dążeń demokratycznych. Dlaczego więc badaczka nie może na takie odczytanie przystać? Ponieważ Ulana jest typowa realizacją modelu ofelicznego - bierna, odpodmiotowiona, niezdolna do tworzenia kultury, bliższa zwierzęciu niż człowiekowi.

Zza współczującego tonu narratora Ulany wyziera obraz bohaterki, której rysy - istoty niecywilizowanej, zdziczałej, półzwierzęcej - i podrzędna pozycja społeczna tworzą związek mający pozory wzajemnego wynikania. Trzeba dużo dobrej woli, by uznać, tak jak Dembowski, że Kraszewski, obarczając Tadeusza winą za upadek moralny chłopki, jej samej przypisuje zdolność do dokonywania właściwych wyborów etycznych (101).

Kraszewski potępia zachowanie panicza, ale nie żąda tym samym sprawiedliwszego porządku społecznego. Co więcej, konserwuje go, ponieważ sugeruje, iż inny model nie jest możliwy, zaś pojedyncze wybryki szlachty można skutecznie korygować. Dziwne, iż ten szowinistyczny i konserwatywny wydźwięk umknął przez lata badaczom Kraszewskiego; co więcej, wielokrotnie podkreślano przecież jego wrażliwość społeczną oraz empatię w stosunku do kobiet - ich postacie miały być skonstruowane znacznie lepiej od męskich bohaterów ${ }^{1}$.

To, że interpretatorzy reprezentujący odmienne interesy i stanowiska ideologiczne przeoczają protekcjonalny, odpodmiotawiający ton Ulany, świadczy dobitnie o sile oddziaływania ofelicznego obrazu, który jest dla nas tak naturalny i przezroczysty, że nie uderza już ukryta w nim przemoc. Czeczot tropi wiktymizujące, paternalizujące interpretacje, które, wyrażając współczucie wobec kobiecych bohaterek, chcą je jednocześnie pozbawić sprawczości, unieruchomić w estetycznym obrazie, jak zasuszony kwiat. Tak na przykład postępuje Stefan Chwin, który odczytuje Miłość Adeli H. Truffaut jako opowieść o ofierze,

1 W ten sposób piszą m.in. Józef Bachórz, Kazimierz Czachowski czy Wincenty Danek. Mateusz Skucha, autor bardzo interesującej rozprawy o problematyce płci w późnym pisarstwie Kraszewskiego (gdzie dowodzi, że Bolesławita pokazuje zarówno męski, jak i kobiecy gender jako produkt regulacji i normatywizacji, jako konstrukt, a tym samym wskazując na proces denaturalizacji tradycyjnej męskości), zauważa, iż Kraszewski od samego początku twórczości jest „wyczulony na nierówność społeczną i dyskryminację kobiet” [17]. Jednocześnie jednak kilka stron wcześniej stwierdza, że jego wyczulona na problem płci lektura musi iść nieco wbrew intencjom samego Kraszewskiego, jest twórczą zdrada - przeczuwając, że sam Bolesławita nie był tak postępowy, jak mógłby sobie tego życzyć krytyk. Innymi słowy, Kraszewski jest raczej sejsmografem, uważnym świadkiem wyłaniania się nowych idei niż ich orędownikiem. W kwestii poglądów politycznych Kraszewskiego jego badacze lubią chować się za formułą o chwiejności jego poglądów - znajdując wiele argumentów na niestabilność przekonań pisarza, który raz brata się z koteria petersburską, by za chwilę chcieć „podpalać Europę z czterech rogów”, moga zawiesić rozstrzygające odpowiedzi. Argumentacja Czeczot pozwoliłaby odrzeć Kraszewskiego z nimbu niezdecydowanego, nieustannie wahającego się romantyka i wskazać na twardy, konserwatywny rdzeń jego myślenia. 
ukształtowanej przez zewnętrzne okoliczności (śmierć siostry, obyczajowość XIX wieku). Tam, gdzie uprzedmiotawiająca narracja widzi oszalałe z miłości biedne dziecko, Czeczot dostrzega odważną kobietę, która nie boi się postępować w zgodzie ze swoim pragnieniem. Brawurowa interpretacja filmu Truffaut odkrywa coś jeszcze: córka Victora Hugo, najsławniejszego człowieka na ziemi, „walcząc o prawo do miłości, walczy o prawo do współtworzenia kultury" (168), o samą siebie, o to, by nie zostać zredukowaną do bycia córką swego ojca. Adèle nie chodzi wcale o porucznika Pinsona, którego nęka natrętnymi awansami, ale o samą siebie. Miłość jest dla niej drogą do wyzwolenia, materiałem jej twórczości - pisząc, próbuje wyzwolić się od wpływu ojca, pisarza-celebryty, i zyskać niezależność.

Mimo że Adèle w filmie Truffaut cały czas pisze - co daje nam do zrozumienia, że przekazana na ekranie historia oparta jest na jej zapiskach - to w istocie fabuła filmu uwzględnia narracje innych, szczególnie jej rodziny. Co ma zrobić córka Victora Hugo, by usłyszano jej własny pisarski głos? Czeczot przywołuje tu argumentację właśnie Blooma - gdyby chodziło o relację między mężczyznami, ojcem i synem, mistrzem i adeptem, sytuacja byłaby jasna: należy unieważnić przodka w cyklu opisanych w Leku pržed uplywem sześciu stadiów rewizyjnych, gdzie, ruchem dialektycznym, raz kwestionując poprzednika, raz się do niego zbliżając, raz eksponując różnicę, raz ją unieważniając, męski podmiot może skłamać præ̌eciw czasowi i poprzedzić swojego poprzednika, spłodzić samego siebie.

Co jednak ma w tej sytuacji począć kobieta-adeptka? Czeczot wskazuje tu na odpowiedź udzielona przez Gilbert i Gubar w kanonicznej rozprawie Madwoman in the Attic, ale wydaje sie, że ich koncepcja lęku przed autorstwem, który pojawia się u piszących kobiet z powodu braku poprzedniczek, nie wyczerpuje zagadnienia, a w istocie cały Ofelizm analizuje, podchodząc od różnych stron, ten właśnie problem. Jak z martwego obiektu, tworzywa sztuki kobieta może stać się autorką, twórczynią? Jak może stać się silną podmiotką - nie analogonem męskiego silnego poety, ale kimś, kto na własnych prawach rodzi sam siebie, poprzedza swojego poprzednika, aktywnie tworzy tradycję, a nie jedynie posłusznie zajmuje przypisane przez nią miejsce?

Być może przypadkowo, Ofelizm składa się z sześciu rozdziałów - tyle samo strategii rewizyjnych wyróżnia Bloom. Ostatnia z tych faz jest apophrades, powrót zmarłych, gdzie silny podmiot jedna się z tymi, z którymi walczył - i być może ta ostatnia faza, kiedy walka o pierwszeństwo jest już skończona i wygrana, sens całego boju zostaje zakwestionowany. U Czeczot ostatni rozdział poświęcony jest artystce, twórczyni, która nie tylko ironicznie przechwytuje ofeliczny obraz, ale afirmatywnie go wykorzystuje, tworzy dzięki niemu, a nie mimo niego czy wbrew jemu - to, co mogło ją okaleczać, czyni częścią swojej tradycji, inkorporuje. Obraz ofeliczny, który był sposobem na zagłuszenie kobiet, tu staje się materiałem, z którego produkuje się własny głos. 
Mowa o Julianie Snaper, która - jak syrena - śpiewa pod woda. Jak Ofelia, w przemoczonej sukni tkwi w zbiorniku z wodą, bliska śmierci (może jej np. wybuchnąć płuco), zmuszona do nadludzkiego wysiłku, ryzykuje także tym, że przedstawia model podmiotowości sprzeczny z obowiązującym normatywnym ideałem modernitas. Syrenę Snaper Czeczot zestawia z passusem z Dialektyki ośniecenia, gdzie Adorno i Horkheimer upatrują w sprycie Odyseusza opierającego się głosowi syren, zagłuszającego to, co kuszące, nieracjonalne, emocjonalne i cielesne - paradygmatyczną postawę nowoczesną.

O wiele bardziej interesujący niż ta opozycja jest nie podjęty przez autorkę temat zanurzonej w zbiorniku wodnym (zamkniętym akwenie, nie rzece) Snaper jako obrazu powrotu do matczynego łona, wód płodowych. Być może na tym polega sukces artystki, że potrafi sama siebie urodzić, stać się własną matką - a tym samym staje na równorzędnej pozycji z męskimi silnymi poetami. Urodzenie samej siebie, niepotrzebowanie matki może stanowić odpowiednik konfrontacji męskiego podmiotu z symbolicznym ojcem.

Ojciec Hamleta, choć martwy, powraca zza grobu i stanowi dla syna ważny punkt odniesienia, obiekt zmagań - zaś o matce Ofelii w dramacie nie pojawia się żadne słowo. Czeczot pomija pytanie o nieobecność matki Ofelii, pomija też możliwe więzi horyzontalne z innymi kobietami: siostrami, przyjaciółkami. Bohaterki - i bohaterowie - tej książki są samotne. Mają za sobą co prawda różne pozytywne kobiece zbiorowości (rusałki, chłopki, Amazonki etc.), ale są od nich odseparowane - te kobiece kolektywy stanowia raczej intelektualny kontekst i tło, a nie rezerwuary, z których bohaterki mogłyby pozyskiwać energię i wsparcie. Tak, jak Juliana Snaper nie potrzebuje matki, bo sama z tworzywa swojej muzyki czyni sobie łono, tak i Esther ze Szklanego klosza przy pomocy ironii (dla Czeczot, podobnie jak dla Blooma, ironia jest strategia podmiotu, a nie właściwością języka) czy Adèle Hugo przez pisanie i strzeżenie swojej walizki z zapiskami radzą sobie same, nie chcą wsparcia innych kobiet. Są samowystarczalne, same rodzą swoich rodziców, i nie potrzebują wspólnoty.

Wywrotowość książki Czeczot polega na tym, że zachowując ambiwalencję i wewnętrzne sprzeczności obrazu ofelicznego pokazuje wojowniczki tam, gdzie fallogocentryczna tradycja każe nam widzieć bierne, pasywne, kruche dziewczęta z kiczowatego prerafaelickiego obrazu. (Podobnie zresztą ma się rzecz z mężczyznami - Valentino, Werter czy Gustaw z IV części Driadón przez swoje ofeliczne identyfikacje odsłaniaja agoniczne oblicze). Jej stawka jest kobieca sprawczość, ale tekst pozostawia niedosyt w zakresie pytania o kobiecą wspólnotę i solidarność. Czy Ofelie są skazane na samotną walkę? W jakich warunkach udałoby się spotkać i zewrzeć szeregi? 
Ewa Wojciechowska - przygotowuje doktorat poświęcony romantycznej noweli fantastycznej na Wydziale Polonistyki UJ.

\section{DANE ADRESOWE:}

Katedra Historii Literatury Oświecenia i Romantyzmu

Wydział Polonistyki UJ

ul. Gołębia 20

30-007 Kraków

EMAIL: wojciechowska.ewka@gmail.com

CrTowANIE: Wojciechowska, Ewa. 2018. „Jak urodzić samą siebie?” Praktyka Teoretyczna 3(29): 148-153.

DOI: $10.14746 /$ prt.2018.3.8

AuTHOR: Ewa Wojciechowska

TITLE: How to give birth to yourself?

ABSTRACT: The book review: Katarzyna Czeczot. 2016. Ofelizm. Romantyczne rawtaszcrenia, feministyczne interwencje. Warszawa: Wydawnictwo IBL PAN.

KEYWORDS: emancipation, feminism, literature, romanticism 